\title{
戸建住宅の外壁に関する地震時損傷リスク評価手法の提案とその適用結果 PROPOSAL AND THE APPLICATION RESULTS OF EARTHQUAKE DAMAGE RISK EVALUATION METHOD OF EXTERNAL WALL IN DETACHED HOUSES
}

\author{
齋 藤 茂 樹*, 深尾 精一** \\ Shigeki SAITO and Seiichi FUKAO
}

\begin{abstract}
The aim of this research is to propose the earthquake damage risk evaluation method of external wall in detached houses, based on the result of the past experimental studies. Moreover, the validity of the method is verified by applying the technique in build-up areas.

Fragility curves for buildings and the layer deformation capability of external wall were used to evaluate the damage risk of external wall by earthquake. Moreover, the external wall damage risk in three buildup areas was evaluated based on this method. Consequently, the risk of external wall damage in old build-up area is high.
\end{abstract}

\section{Keywords : detached houses, external wall, non-structural element, damage risk of earthquake, high density wooden built-up area 户建住宅、外壁、非構造部材、地震被害リスク、木造住宅密集地域}

\section{1. 序章}

近年発生する大地震では、非構造部材の被害が多く報告されてい る。しかし、戸建住宅の外壁に関しては、被害が広範囲に分布する ことなどから正確な被害実態が把握され難く、十分な研究が行われ てきていないのが現状である。しかし、市街地における外壁の地震 被害は、人命の危険や財産の損失に繋がるだけでなく、延焼などの 二次災害発生のリスクを高めるなど多くの損害をもたらすため、十 分な対策をとる必要がある。また、東京都には地震火災に対して脆 弱だと言われる木造住宅が密集した市街地が数多く存在する。東京 都の被害想定 ${ }^{1}$ によると、関東南部に M 7 程度の地震が冬季の夕方、 風速 $15 \mathrm{~m} /$ 秒の条件下で起こった場合、市街地火災の発生によって 死者数 6 千人強 ( ちち地震火災による死者数 3 千人強) 、建物被害 47 万棟（うち消失棟数 34 万棟）という深刻な被害が起こるとされ ており、地震火災の防止がいかに緊急を要する課題であるかが伺え る。

東京消防庁火災予防審議会答申2) の中で、延焼速度比算定にあた りモルタル外壁のひび割れと火災危険温度 $\left(260^{\circ} \mathrm{C}\right)$ 到達時間との 関係についての実験結果が示されており、ひび割れによる防火性能 の低下が指摘されている。また、「東消式 2001」3) では、地震によ る加速度と壁面崩落率の関係について、震度 5 弱（90gal）で $0 \%$ 、
震度 7 （895gal） で $18 \%$ となるような線形回帰モデルが採用されて いる。このように、地震火災の延焼速度を求める際には外壁損傷の 影響を考慮する試みは行われているが、外壁構法ごとの耐震性や地 震時の損傷リスクを考慮したうえでの評価は行われていない。より 精度の高い地震火災の延焼予測を行うには、より詳細な外壁損傷の 実態を独立に評価し、延焼危険性の評価に組み込む必要がある。

非構造部材としての外壁構法の耐震性能に関する既往の研究は数 多くなされている4) 17)。その多くが外壁構法の層間変位追従性能 を実験によって評価するものであり、様々な条件の下で行われてい る。しかし、いずれの研究も実際の建物における外壁の損傷リスク を論じることはしていない。また、これらの実験結果をある基準に よってまとめ、外壁構法ごとの耐震性能を評価した研究も金子ら ${ }^{18)}$ によって行われているが、中高層建物を対象とした分析であるため 戸建住宅に直接適用寸ることはできない。一方で、建物の構造体に ついては過去の地震被害調查の結果をもとにして被害関数の提案が 様々になされており 19) 24)、想定する地震動における建物被害確率 を求めることができる。しかし、非構造部材の被害までをも評価す る手法は用意されていない。非構造外壁、建物構造体双方の知見を 集約し、外壁構法の地震時損傷リスクを評価することが、総合的な 防災対策にとって重要な意味を持つと考える。

\footnotetext{
* 首都大学東京大学院都市環境科学研究科 博士後期課程 - 修士 (工学)

$* *$ 首都大学東京大学院都市環境科学研究科 教授. 工博

Graduate Student, Graduate School of Urban Environmental Sciences, Tokyo Metropolitan Univ., M. Eng.

Prof., Graduate School of Urban Environmental Sciences, Tokyo Metropolitan Univ., Dr. Eng.
} 
以上より、外壁構法の地震時損傷リスクを評価し、多角的な防災 性評価に供する有用な資料を作成することを本研究の目的とする。

\section{2. 研究の概要}

外壁の耐震性能は、主に非構造部材の耐震性を研究する分野で扱 われている。非構造部材の地震動による損傷は、構造体の挙動の影 響を大きく受ける。従って、外壁の地震時の損傷リスクを求めるに は、構造体の損傷リスクを同時に評価する必要があり、それと外壁 構法ごとの耐震性との関係によって評価されるべきものである。そ こで、本研究では構造体の地震時損傷リスク、外壁の層間変位追従 性能を評価することにより、外壁の地震時損傷リスクを求めること とする。この評価の考え方は、日本建築防災協会と建築・設備維持 保全推進協会が発行している「外壁の地震に対する安全性の評価方 法・同解説」 25) に準じている。すなわち、主体構造と外壁構法の性 能をそれぞれ定性的に評価し、その関係によって地震時の損傷リス クを求めている。

\section{3. 構造体の地震時損傷リスク}

\section{3-1. 建物被害関数の概要}

建物の地震損傷のリスクを評価する方法については、様々な手法 が提案されているが、本研究では東京都が行っている地震に関する 地域危険度調查（第6 回）26) において、建物倒壊危険度の測定に 使用されている手法を引用する。これは村尾ら 21)、22) が 1995 年兵 庫県南部地震における神戸市灘区の建物被害の実デー夕を基に建物 倒壊危険度の評価方法を提案したものであり、同一の指標によって 様々な条件の建物被害確率を求めることが可能である。また、個々 の建物の全壊被害確率を求めることが可能であるためミクロな被害 予想にも対応できると判断し、本研究では建物倒壊危険度測定の方 法を用いることとした。この他に、個別の建物について耐震診断な どの目的で詳細な調查を行う場合には、建物剛性によって構造体の 損傷リスクを評価することが考えられるが、本研究では扱わないこ ととする。

村尾らの提案した建物全壊確率を表した被害関数（以下では単に 被害関数と呼ぶ）は、地震最大速度と建物強度確率分布の関係が対 数正規分布に従うと仮定して確率密度関数を求め、地盤ごとの地震 最大速度正規確率密度分布と比較することによって建物被害確率を 求めている。ここで、外壁は構造体が全壊注1)の際にはほぼ確実に 大きな損傷を受けるため、全壊を前提とした被害関数を評価指標と して用いるのは必ずしも適していない。構造体が倒壊に近いほどの 変形を受けるような変位は非構造外壁の設計性能としては想定され ておらず、このような状況においては外壁の損傷を防ぐことよりも、 外壁損傷による二次災害を防止する策を講じることが効果的であ り、また有効でもあるためである。従って、より軽微な構造体の損 傷に対する外壁損傷のリスクを評価することが重要である。そこで、 本研究では被害関数を用いて建物の半壊率を求め、その值より建物 損傷リスクを評価することとする。

建物強度の確率密度関数 $R$ と、地盤ごとの PGV（最大速度）生 起確率による建物の損傷確率分布関数 $S$ はいずれも対数正規分布に 従うと仮定されており、その確率分布関数 $f(x)$ は一般に以下の式 によって導かれる。

$$
f(x)=\frac{1}{\sqrt{2 \pi} \xi x} \exp \left[-\frac{1}{2}\left(\frac{\ln x-\lambda}{\xi}\right)^{2}\right] \quad(0<x<\infty)
$$

ここで、入は平均值、らは標準偏差を表している。以下に、村尾ら による文献 22 より、建物強度と地盤ごとの PGV 生起確率密度関数 を用いた建物の被害確率算出の方法を引用寸る。引用部分の式番号 は原文のままである。

『建物強度の確率密度関数を $R$ 、地形区分ごとの $\mathrm{PGV}$ 生起確率密 度関数を $S$ とおくと、全壊の確率 $P_{f}$ は、次の式で表される。

$$
\begin{aligned}
& P_{f}=P\left(\frac{R}{S}<1\right) \\
& \text { ここで、 } Z=R / S \text { と置くと、上式より、 } \\
& P_{f}=\int_{0}^{1} f_{z}(z) d z
\end{aligned}
$$

となる。ところで、R、S は対数正規分布を仮定しており、その自 然対数はその平均值をそれぞれ $\lambda_{r} 、 \lambda_{s}$ 、標準偏差を $\xi_{r} 、 \xi_{s}$ とすれば、 $\ln Z=\ln R-\ln S$ より、 $\ln Z$ も正規分布となる。ここで $R$ と $S$ が無相間 と仮定すれば、 $\ln Z$ の平均值及び標準偏差はそれぞれ、 $\lambda_{z}=\lambda_{r}-\lambda_{s}$ 、 $\xi_{z}=\sqrt{\xi_{r}^{2}+\xi_{s}^{2}}$ で与えられる。よって、

$$
\begin{gathered}
P_{f}=\frac{1}{\sqrt{2 \pi} \xi_{z}} \int_{0}^{1} \frac{1}{z} e^{-\frac{1}{2}\left(\frac{\ln z-\lambda_{s}}{\xi_{z}}\right)^{2}} d z \\
y=\frac{\ln z-\lambda_{z}}{\xi_{z}} \text { と变換すると、 } \\
P_{f}=\frac{1}{\sqrt{2}} \int_{-\infty}^{\lambda_{z}} e^{-\frac{1}{2} y^{2}} d y=1-\Phi\left(\frac{\lambda_{z}}{\xi_{z}}\right)
\end{gathered}
$$

となり、ある $R$ と $S$ に対する破壞確率が決定される。ここで $\Phi\left(\lambda_{z} / \xi_{z}\right)$ は標準正規確率分布関数である。』

\section{3-2. 建物損傷リスク $\mathrm{F}$ の評価}

戸建住宅の半壞率は、 $R 2<R 1$ の範囲において、全半壊率 $R 1$ か ら全壊率 $R 2$ を差し引いたものとし（図 1 中のハッチング部分）、特 定の地盤における $\mathrm{PGV}$ 生起確率 $S$ 上る建物被害発生確率は $R<S$ の範囲における累積確率となる (図 1 中の薄墨部分の面積)。本研 究では全半壊建物被害関数および全壊建物被害関数を導くのに、村 尾らの文献 21 中の表 4 に示された兵庫県南部地震における神戸市

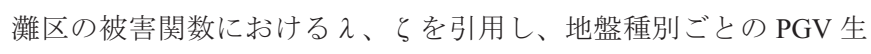

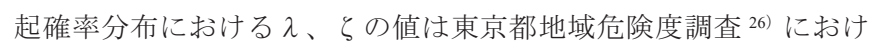

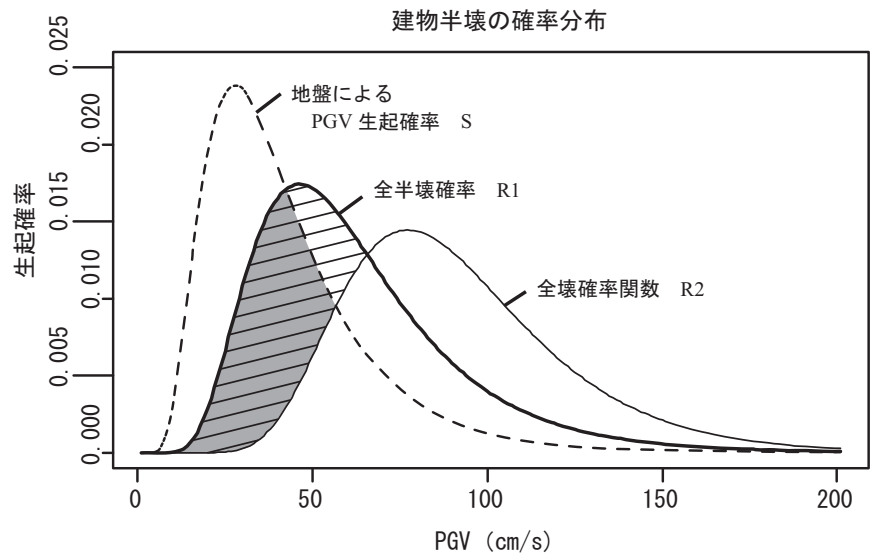

図 1 構造体半壊確率算出の概念図 
表 1 構造体の半壊確率と地震時損傷リスク $\mathrm{F}$

*文献 26 を基に筆者が作成

\begin{tabular}{|c|c|c|c|c|c|c|c|c|c|c|c|c|c|c|c|c|}
\hline \multirow{4}{*}{ 構造 } & \multirow{4}{*}{ 建設年 } & \multirow{2}{*}{\multicolumn{2}{|c|}{ 全半壞 }} & \multirow{2}{*}{\multicolumn{2}{|c|}{ 全壞 }} & \multicolumn{11}{|c|}{$\lambda s$} \\
\hline & & & & & & 山地-丘陵 & 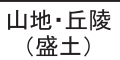 & 台地1 & 台地2 & 谷底低地 1 & 谷底低地2 & 沖積層1 & 沖積層2 & 沖積層3 & 沖積層4 & 沖積層5 \\
\hline & & \multirow{2}{*}{$\lambda r_{1}$} & \multirow{2}{*}{$\zeta r_{1}$} & \multirow{2}{*}{$\lambda r_{2}$} & \multirow{2}{*}{$\zeta \mathrm{r}_{2}$} & 3.58 & 3.77 & 3.87 & 3.93 & 4.47 & 4.32 & 3.81 & 4.23 & 4.36 & 4.47 & 4.47 \\
\hline & & & & & & \multicolumn{11}{|c|}{$\zeta \mathrm{s}=0.541$} \\
\hline \multirow{3}{*}{ 木造 } & $\sim 1970$ & 4.02 & 0.456 & 4.45 & 0.342 & 18.08 & 21.72 & 23.38 & 24.13 & 22.58 & 24.49 & 22.41 & 25.10 & 24.09 & 22.58 & 22.58 \\
\hline & $1971 \sim 1980$ & 4.25 & 0.395 & 4.73 & 0.378 & 11.87 & 16.29 & 18.93 & 20.41 & 28.19 & 27.42 & 17.31 & 26.43 & 27.75 & 28.19 & 28.19 \\
\hline & $1981 \sim$ & 4.61 & 0.474 & 5.12 & 0.496 & 5.86 & 8.78 & 10.77 & 12.01 & 23.42 & 20.50 & 9.52 & 18.69 & 21.32 & 23.42 & 23.42 \\
\hline \multirow{3}{*}{ RC造 } & $\sim 1970$ & 4.72 & 0.691 & 5.14 & 0.646 & 6.53 & 8.70 & 10.07 & 10.88 & 17.42 & 15.87 & 9.22 & 14.87 & 16.32 & 17.42 & 17.42 \\
\hline & $1971 \sim 1980$ & 4.85 & 0.612 & 5.33 & 0.575 & 4.70 & 6.84 & 8.31 & 9.22 & 18.22 & 15.74 & 7.39 & 14.29 & 16.41 & 18.22 & 18.22 \\
\hline & $1981 \sim$ & 5.33 & 0.789 & 6.00 & 0.789 & 2.82 & 4.13 & 5.06 & 5.66 & 12.88 & 10.56 & 4.47 & 9.35 & 11.16 & 12.88 & 12.88 \\
\hline \multirow{3}{*}{ 鉄骨造 } & $\sim 1970$ & 4.25 & 0.712 & 4.64 & 0.619 & 12.87 & 15.03 & 16.11 & 16.65 & 17.93 & 18.27 & 15.47 & 18.22 & 18.23 & 17.93 & 17.93 \\
\hline & $1971 \sim 1980$ & 4.49 & 0.549 & 4.97 & 0.490 & 9.10 & 12.42 & 14.49 & 15.70 & 24.26 & 22.58 & 13.22 & 21.33 & 23.10 & 24.26 & 24.26 \\
\hline & $1981 \sim$ & 5.01 & 0.733 & 5.64 & 0.731 & 4.68 & 6.64 & 7.98 & 8.81 & 17.68 & 15.06 & 7.14 & 13.61 & 15.76 & 17.68 & 17.68 \\
\hline \multirow{3}{*}{ 軽S造 } & $\sim 1970$ & 4.41 & 0.504 & 4.70 & 0.550 & 5.79 & 7.88 & 9.17 & 9.92 & 14.94 & 14.02 & 8.38 & 13.30 & 14.31 & 14.94 & 14.94 \\
\hline & $1971 \sim 1980$ & 4.95 & 0.855 & 5.82 & 0.972 & 6.62 & 8.85 & 10.33 & 11.23 & 20.44 & 17.75 & 9.41 & 16.26 & 18.46 & 20.44 & 20.44 \\
\hline & $1981 \sim$ & 5.28 & 0.865 & 6.19 & 1.101 & 3.14 & 4.48 & 5.43 & 6.04 & 13.25 & 10.93 & 4.83 & 9.72 & 11.52 & 13.25 & 13.25 \\
\hline \multicolumn{2}{|c|}{ その他 } & 4.02 & 0.456 & 4.45 & 0.342 & 18.08 & 21.72 & 23.38 & 24.13 & 22.58 & 24.49 & 22.41 & 25.10 & 24.09 & 22.58 & 22.58 \\
\hline & & & & & & & & 15 & & $\mathrm{~F}_{4}$ & & $\mathrm{~F}_{3}$ & & $\mathrm{~F}_{2}$ & & $\mathrm{~F}_{1}$ \\
\hline & & & & & & & & $0 \sim 25$ & & $5 \sim 20 \%$ & 20 & $\sim 15 \%$ & & $\sim 10 \%$ & & $\% \sim$ \\
\hline
\end{tabular}

る建物倒壊危険度測定に使用されている、基盤速度 30kine における 地盤の増幅率を考慮した地表面最大速度の值を引用して求めた。以 上の結果を基に、地震による構造体の損傷リスクを「構造体損傷 リスク F」とし、グレードを設定した。今回は便宜的に半壊率 0 〜 $10 \%$ をグレードF $1 、 10$ 〜 15\% をグレード F $2 、 15$ ～20\%をグレー ドF3、20〜25\%をグレードF4、25～30\%をグレードF5 と設定した。 このようにして求めた建物半壊率と、その值による構造体損傷リス クのグレードを表 1 に示す。

構造体の地震被害は、建物の摇れによってのみ起こるのではなく、 液状化現象などの地盤の損傷によっても引き起こされるが、地盤の 変化による構造体の被害は上記の手法では表すことができない。こ れは液状化などによる地盤の変形は建物の不同沈下を起こし、構造 体の種類や建設年代ではなく基礎形式や杭の有無によってその被害 程度が大きく異なるためである。本研究では、液状化現象による構 造体の被害はその性質上大破以上であるとし、構造体の損傷リスク の評価には含まないこととする。

\section{4. 外壁の層間変位追従性能}

\section{4-1．既往研究による外壁構法の層間変位追従性能の整理}

非構造部材の耐震設計の考え方は、坂本ら 27)によって提唱され たものが基本となっている。つまり、建物構造体のように外力に対 して必ずしも破壊されないことを第一の目標とするのではなく、直 接的・間接的にも人命の危害を加えないような総合的な安全性の確 保、損傷時であっても確保す心゙き性能の設定、機能・性能の回復に 要するコストの想定などが重要であるという考え方である。外壁の 耐震性能は慣性力と層間変位追従性能によって評価されるが、戸建 住宅の外壁耐震性において主に問題となるのは層間変位追従性であ る。従って、本研究においては外壁の耐震性能は層間変位追従性能 によって評価することとする。

各種外壁構法の層間変位追従性能に関しては、既に様々な試験が
表 2 損傷程度による外壁被害の評価

\begin{tabular}{|c||c|l|}
\hline \multicolumn{1}{|c||}{ ランク } & \multicolumn{2}{|c|}{ 損傷の程度での評価 } \\
\cline { 2 - 3 } & \multicolumn{1}{|c|}{ 湿式外壁 } & \multicolumn{1}{c|}{ 乾式外壁 } \\
\hline \hline \multirow{2}{*}{ 軽微 } & $1 \mathrm{~mm}$ 未満のひび割れ & 残留変形 \\
\cline { 3 - 3 } & & クラックの発生 \\
\hline \multirow{2}{*}{ 中破 } & $1 \mathrm{~mm}$ 上のひび割れ & パネル端部の欠け \\
\cline { 2 - 3 } & 剥離の発生 & シールの切れ \\
\cline { 2 - 3 } & 部分的な剥落 & 取付け金物の損傷 \\
\hline 大破 & 全面的な剥離·剥落 & パネルの脱落 \\
\hline \multirow{2}{*}{} & &
\end{tabular}

表 3 荷重 - 変形関係による外壁被害の評価

\begin{tabular}{|c||c|c|}
\hline \multicolumn{1}{|c||}{ ランク } & \multicolumn{2}{c|}{ 荷重一変形曲線での評価 } \\
\cline { 2 - 3 } & $\begin{array}{c}\text { Bi-Linear型 } \\
\text { (完全弾塑性モデル) }\end{array}$ & Tri-Linear 型 \\
\hline \hline 軽微 & 特異点 (降伏変位 $\left.\delta_{y}\right)$ & 特異点1 \\
\cline { 3 - 3 } 中破 & 特異点2 \\
\hline 大破 & 荷重最大点 & 荷重最大点 \\
\hline
\end{tabular}

行われている。金子ら ${ }^{18)}$ はこれらの実験結果と過去の地震被害の 関係を明らかにすると共に、非構造部材の耐震性能を 4 種類に分類 している。しかし、ここで用いられている外壁構法は中高層建物に 主に用いられるものであり、戸建住宅に広く用いられているラスモ ルタルやサイディングなどの評価は行われていない。そこで、本研 究では戸建住宅に主に用いられているラスモルタル、サイディング、 $\mathrm{ALC}$ パネルについて、既往の各種外壁構法の実験結果を基に層間 変位追従性能を評価する。ここで、各研究における実験はそれぞれ 異なった目的で行われており、その結果の表記方法は様々であるた め、多様な表記方法に対応した外壁被害のランクを設定する必要が 
表 4 既往の実験結果による外壁構法の層間変位追従性能の整理

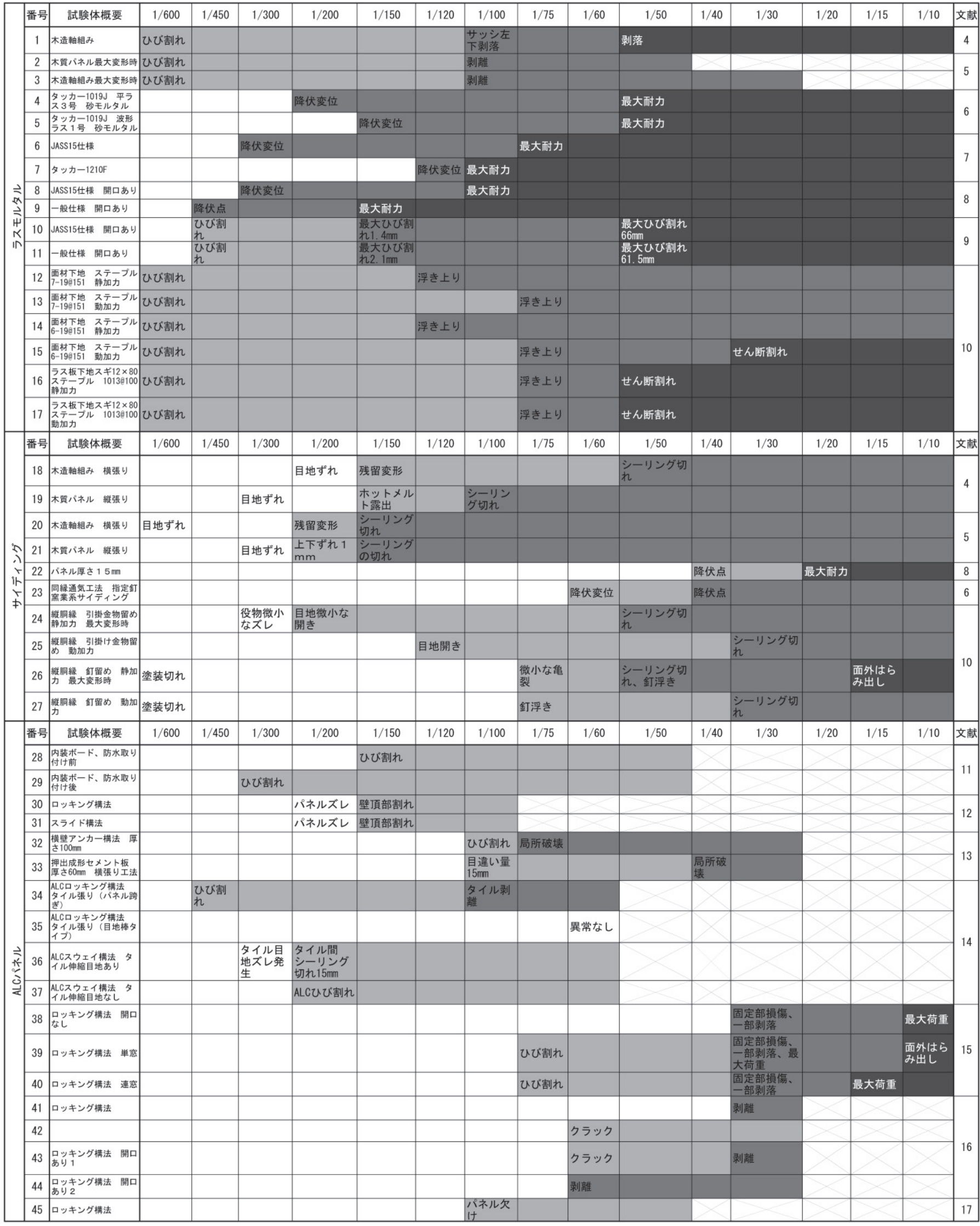


ある。本研究では表 $2 、 3$ に示すように、外壁損傷の程度、荷重一 変形曲線の特徴点それぞれに対する層間変形角によって損傷ランク を設定した。

損傷程度による分類は、その損傷による補修の有無や性能低下を 考慮して設定した。1 $\mathrm{mm}$ 未満の軽微なひび割れや乾式外壁パネル の軽微なクラックは、美観の損失は伴うが大きな性能低下には繋が らないため、軽微な損傷とした。これらの損傷が伸展し、大きなひ び割れや剥落の発生、シーリングの切れなどに発展すると、耐力の 低下や漏水が䀣念され、補修が必要になるため中破とする。大破は 外壁の機能が喪失した状態とし、広範囲の剥落やパネルの脱落がこ れに相当する。補修による性能回復が困難な状況であり、全面的な 改修や部材の交換が必要になる。

荷重一変形曲線でのランク設定の考え方としては、外壁が荷重 (水 平せん断力）を受けると、まずひび割れや留め付け金物周辺で破損 が発生する (軽微および中破)。これにより壁体は塑性変形を始め、 最大耐力では広範囲での脱落や剥落と等しい状態（大破）になると 考えられる。従って、このような状態の変化を表す特異点を基準と して損傷の程度を評価する事とした。

以上の基準に従い、これらの評価点が確認できた文献を基にして 外壁の損傷程度と層間変形角の関係を整理したものが表 4 である。 以下に各外壁構法の層間変位追従性能の傾向を示す。

\section{ラスモルタル}

ラスモルタルの層間変位追従性能に関する実験を行った既往研究 としては、文献 4 〜 7 などが挙げられる。ラスモルタルの層間変位 追従性能は、構法によって若干の相違はあるものの、概ね同程度の 性能を示している。すなわち、層間変形角 $1 / 600$ 程度の小さな層間 変位から軽微な損傷が発生し、1/100 から $1 / 150$ 程度で中破に至る。 層間変形角 $1 / 50$ 程度で大破となるが、層間変位追従性能の低い構法 を用いている場合には $1 / 100$ 程度の層間変形角でも大破に至る可能 性がある。

表 4 の 9 番の試験体は宮村らがラス下地モルタルの施工実態を調 查した結果に基づいて作成した試験体であり、他のラスモルタル構 法と比較して相関変形追従性能が低いことがわかる。大地震時には 大きな剥落を起こす危険があり、一般的に使用されているラスモル タル構法の耐震性の低さが現れている。

\section{サイディング}

サイディングの層間変位追従性能を評価した実験は文献 $4 \sim 6 、 8$ 、 10 が挙げられる。サイディングは他の外壁構法と比較して層間変位 追従性能に関する評価実験が少なく、多くの実験が他の外壁構法と の比較のために行われている。実験方法による層間変位追従性能の ばらつきが大きいが、中破以上の損傷を受けるものはほとんどなく、 性能は概して高いといえる。層間変形角 1/300 以下の小さな変形で は被害はほとんど発生せず、その後目地の開きやシーリングの切れ といった損傷が発生するが、板の大きな損傷や脱落などの被害はか なり大きな変形でも発生しない。

\section{ALCパネル}

$\mathrm{ALC}$ パネルの層間変位追従性能を評価した害験は文献 $11 〜 17$ な ぞが挙げられる。これらは主に中高層建物に用いられる ALC パネ ルを想定してるが、本研究ではこれらの結果を戸建住宅に用いられ る構法とみなして分析を行う注2) ALC パネルの構法のうち、ロッ
キング構法とスライド構法、スウェイ構法は層間変位追従性を向上 させることを目的として挿入筋構法に替わって開発された構法であ る。既往の実験研究の結果を見ると、これらの構法の層間変位追従 性のの高さが証明されている。ALC パネルが最も多く用いられてい る中高層鉄骨造の地震時想定最大変形角は $1 / 200$ とされおり、そ の程度の変形に対しては十分な性能を有していることがわかる。た だし、他の ALC パネル構法と比較して層間変位追従性能が低いと されている挿入筋構法に関する実験結果はあまり見らなかった。近 年の中・大規模の地震における ALC パネルの被害の多くがこの構 法を用いており、既存の建物の多くがこの挿入筋構法を使用してい ると考えられるので、より多くの情報の整備が必要である。

\section{4-2. 外壁構法の層間変位追従性能 $\mathrm{L}$ の評価}

表 4 の結果を基に、外壁構法の層間変位追従性能の評価を行う。 戸建住宅には地震時における主体構造に対する層間変形角の設定が されておらず注3)、帳壁の構造方法を定めた昭和 46 年建設省告示第 109 号においては 3 階建て以上で高さ 31 メートルを超える建築物の 屋外に面する帳壁に対して「その高さの $1 / 150$ の層間変位に対して 脱落しないこと」と定められている。また、公共建築協会が発行す る「官庁施設の総合耐震計画基準及び同解説」においては、構造種 別に応じた層間変形角の最大值として、RC 造、SRC 造は $1 / 200 、 S$ 造は $1 / 100$ が設定されている。これらいずれの規定も、2 層以下の 木造が主要な戸建住宅の外壁には適した評価方法とはいえない。

上述した主要構造および外壁の最大層間変形角の設定は、昭和 47 年度から 5 年間に亘って行われた建設省の総合技術開発プロジェク 卜「新耐震設計法の開発」の成果に基づいていると考えられる。そ の報告書の中には、非構造部材の変形性能規定值である $1 / 150$ は剛 性の低い鉄骨純ラーメンなどを想定しているとあり、極めてまれな 地震に対しては $1 / 75$ で部材の脱落・飛散等を生じないこととする考 えが示されている。また、剛性が高い壁式 RC 造等については変形 性能規定值の $1 / 2$ にあたる $1 / 300$ を層間变形角の規定值としても不 都合はないであろうとされている。本研究ではこの建物の剛性を基 準としたこの規定值を基に、戸建住宅における外壁構法の層間変位 追従性能の評価を行うこととする。

地震規模に応じた層間変形角を表 5 のように設定した。この各規 定值に対して、表 5 で定めた外壁損傷の程度がどのように対応寸る かによって「外壁構法の層間変位追従性能 L」を、グレード L1 〜 L5 と設定して評価した。

表 5 外壁構法の層間変位追従性能に着目したグレード $\mathrm{L}$

\begin{tabular}{|c|c|c|c|c|c|c|c|}
\hline 層間変形角 & $\mathrm{L}_{5}$ & \multicolumn{2}{|c|}{$\mathrm{L}_{4}$} & $\mathrm{~L}_{3}$ & \multicolumn{2}{|c|}{$\mathrm{L}_{2}$} & $\mathrm{~L}_{1}$ \\
\hline $1 / 75$ & 無被害 & 軽微 & 軽微 & 中破 & 中破 & 中破 & 大破 \\
\hline $1 / 150$ & 無被害 & 無被害 & 軽微 & 軽微 & 軽微 & 中破 & 中破 \\
\hline $1 / 300$ & 無被害 & 無被害 & 無被害 & 無被害 & 軽微 & 軽微 & 軽微 \\
\hline
\end{tabular}




\section{4-2-1．各外壁構法の層間変位追従性能}

ある特定の建物に関して外壁構法の層間变位追従性能を評価する 際には、表 5 より最も近いと思われる構法の実験結果を参照する。 しかし、詳細な外壁構法は建物所有者であっても把握していないと 考えられる。従って、ある程度大枠で外壁構法を捉え、その層間変 位追従性能を示すことが重要となる。本研究では各実験結果による 層間変位追従性のグレードの相加平均を取り、四捨五入したものを その外壁構法の性能とする。その結果外壁構法ごとの層間変位追 従性能 L のグレードは、ラスモルタルは L2、サイディングは L4、 ALC パネルはL4 となった。この結果は、実験データがより充実す れば変動するものであり、確定的なものではない。

\section{4-2-2. 維持管理および劣化抑制対策による評価}

外壁の耐震性能は劣化状態によって大きく変化する。壁体内結露 が発生すると下地の劣化が進み、外壁構法が本来有している層間変 位追従性能を発揮することができない。そのため定期的な点検およ び補修・改修による外壁性能の維持が非常に重要となる。外壁構法 の劣化と層間変位追従性能の関係は未だ明らかになっていないた め、本研究では劣化と層間変位追従性能の関係を以下のように定性 的に設定する。

ラスモルタルやサイディングなどの耐用年数は小松ら ${ }^{28)}$ による とおよそ 9 〜 14 年である。適切な改修周期の設定には明確な定義 は存在しないが、耐用年数が 1 つ目安となると考えられる。そこで、 新築時もしくは前回のメンテナンスより 10 年以上補修・改修など の維持保全が行われていない場合には層間変位追従性能 L のグレー ドを 1 つ下げる事とする。

通気工法や適切な断熱材の使用などにより、壁体内結露を防止す ることは、外壁の劣化を抑制する上で有効である。逆に、このよう な対策が取られていない場合、取り付け金物や下地が腐朽し、大き く性能を低下させることに繋がる。従って、このような対策が取ら れていない場合には層間変位追従性能のグレードを 1 つ下げること とする。

\section{5. 外壁構法の地震時損傷リスクDの評価}

第 3 章、第 4 章で定めた構造体損傷リスク $\mathrm{F}$ と外壁構法の層間変 位追従性能 Lより、「外壁構法の地震時損傷リスク D」の評価を行 う。本研究では構造体損傷リスク $\mathrm{F}$ と外壁構法の層間変位追従性能 L の組合せによって表 6 のように外壁の地震時損傷リスク $\mathrm{D}$ を設定 した。外壁の地震時損傷リスク D は、構造体の損傷リスクにやや重 点を置いた評価になっており、定性的な指標である。なお、本研究 で示した各評価值は特定の地震動に対する損傷の有無を評価するも のではなく、あくまで地震に対する性能を評価していることに注意 が必要である。また、構造体損傷リスク $\mathrm{F}$ は構造体が地震時に半壊 となる確率を用いて設定したグレードであるが、構造体はその種類 によって剛性が異なり、同じ半壊の損傷であっても、その際の層間 変形角は大きく異なる。ただし、本研究で対象としている戸建住宅 に関してはその多くが木造住宅であり、また、次いで建設数が多い と考えられる軽量鉄骨造の剛性は木造住宅のそれと近いものである として、一つの指標で外壁の地震時損傷リスクを表すこととした。
表 6 外壁構法の地震時損傷リスク D の評価

\begin{tabular}{|c|c|c|c|c|c|c|}
\hline & \multicolumn{5}{|c|}{ 外壁構法の層間変位追従性能 L } \\
\hline & & $\mathrm{L}_{5}$ & $\mathrm{~L}_{4}$ & $\mathrm{~L}_{3}$ & $\mathrm{~L}_{2}$ & $\mathrm{~L}_{1}$ \\
\hline \multirow{5}{*}{ 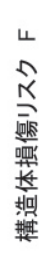 } & $\mathrm{F}_{1}$ & I & $\mathrm{I}$ & I & II & II \\
\hline & $\mathrm{F}_{2}$ & I & $\mathrm{I}$ & II & II & III \\
\hline & $\mathrm{F}_{3}$ & $\mathrm{I}$ & II & II & III & III \\
\hline & $\mathrm{F}_{4}$ & II & II & III & III & IV \\
\hline & $\mathrm{F}_{5}$ & II & III & III & IV & IV \\
\hline
\end{tabular}

I 現状で地震による外壁損傷のリスクはほぼない

II 現状で地震による外壁損傷のリスクは小さい

III 外壁損傷に注意が必要、対策を講じる必要がある

IV

非常に外壁損傷のリスクが高い、早急に対応寸る必要がある 表 7 市街地の概要

\begin{tabular}{|c|c|c|c|c|}
\hline \multicolumn{2}{|c|}{ 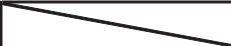 } & 八王子市N地域 & 杉並区M地域 & 中野区M地域 \\
\hline \multicolumn{2}{|r|}{ 指定地域 } & 特になし & 木造住宅密集地域 & 重点整備地域 \\
\hline \multicolumn{2}{|r|}{ 地盤種別 } & 山地-丘陵(盛土) & 台地1 & 台地1 \\
\hline \multirow{3}{*}{ 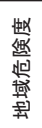 } & 建物倒壊危険度 & 1 & 2 & 3 \\
\hline & 火災危険度 & 1 & 4 & 5 \\
\hline & 総合危険度 & 1 & 3 & 4 \\
\hline
\end{tabular}

表 6 に示した外壁構法の地震時損傷リスクを評価するための構造体 の損傷リスクは、このような前提の上での評価方法となっている。

\section{6. 実際の地域における外壁リスク評価の適用}

筆者ら ${ }^{29)}$ の既往の研究による複数の市街地におけるアンケート 調查の結果を基に、本研究で提案した戸建住宅外壁の地震時損傷リ スク評価を行った。具体的には、各戸建住宅の構造種類、建設年、 外壁種類、外壁改修時の築年数のデータを用いて分析を行っている。 各市街地の概要は表 7 の通りである。杉並区 $\mathrm{M}$ 地域と中野区 $\mathrm{M}$ 地 域は木造住宅密集地域に指定されており、中野区 $M$ 地域は東京都 の「防災都市づくり推進計画（平成 16 年）」において重点整備地 域に指定されている。また、東京都地域危険度調査 ${ }^{26)}$ の結果では、 八王子市 $\mathrm{N}$ 地域は全ての危険度が最も低い 1 であるのに対して、杉 並区 $\mathrm{M}$ 地域と中野区 $\mathrm{M}$ 地域は火災危険度が非常に高く、総合危険 度も高い。

市街地ごとに補修・改修間隔を考慮した外壁の地震時損傷リスク D の評価を行った結果が表 8 ～ 10 である。ここで構造体損傷リス ク $\mathrm{F}$ の評価において、アンケート調査では鉄骨造と軽量鉄骨造の区 別をしていなかったため、本研究では全て軽量鉄骨造とみなした。 いずれの地域も比較的良好な地盤に立地しているため、構造体の損 傷リスク F はさほど高くない。しかし、中野区 M 地域では 1970 年 以前に建設された木造住宅が多く、構造体損傷リスクのグレードが F4の建物が、他の地域と比較して多い。

外壁構法の層間変位追従性能 L の評価では、各地域で最も性能が 低い L1 が比較的多くなっている。これは補修・改修から 10 年以上 経過しているラスモルタルがいずれの地域でも多く存在することを 示している。八王子市 $\mathrm{N}$ 地域は L1 が $22 \%$ 程度であり、中野区 M 地域では 3 割以上が L1 であった。

以上の結果より求めた各市街地における外壁の地震時損傷リスク 
$\mathrm{D}$ は図 2 のようになった。八王子市 $\mathrm{N}$ 地域は外壁の地震時損傷リス ク D がグレードII（以下では D II と表記し、他のグレードも同様 の表記方法とする。）以下が過半数を占めており、比較的被害の広 がりは小さいと考えられる。一方で杉並区 M 地域と中野区 M 地域 はD III以上が過半数を占めており、多くの外壁被害が出ることが予 想される。特に中野区 M 地域においてはランク D III が 41\%、D IV が $13 \%$ と非常に高い值を示しており、特に注意が必要な地域だと いえる。これらの地域は木造住宅密集地域、重点整備地域に指定さ れており、従来より市街地の防災性能が低いことが指摘されている 地域である。外壁の損傷リスクという観点でもこれらの地域が脆弱 であることを示寸結果となり、本研究における外壁の地震時損傷り スク評価手法が従来の地域危険度調查などによる評洒結果と一致し た。また、八王子市 $\mathrm{N}$ 地域においても外壁の地震時損傷リスク $\mathrm{D}$ が D III 以上の建物が 3 割強存在しており、少なからず被害が出るこ とを示唆する結果となった。

\section{7. まとめ}

本研究では、戸建住宅の外壁構法の地震時損傷リスクを建物被害 関数と既往の外壁構法層間変位追従性能実験の結果を用いて評価す る方法を示した。以下に本研究で得た知見を示す。

1）構造体損傷リスク F は構造種別では木造が高く、建設年代別 では 1971 年〜 1980 年に建設された建物が高くなった。これは 1970 年以前に建設されたものは大破となる確率が高く、相対的 にこの年代における中破の確率が下がったためである。

2）ラスモルタルの層間変位追従性能はいずれの試験体においても ほぼ同程度の性能を示しているが、施工方法が適切でないもの はその性能が大きく低下することが示唆されている。

3 ) サイディングの層間変位追従性能に関寸る実験研究は多くは行 われおらず、それぞれの実験で示される結果もばらつきが大き い。しかし、その層間変位追従性能は概初良好であり、大きな 層間変形角においても被害は中破に止まることが確認できる。 また ALC パネルも同様の傾向を示している。

4）外壁構法ごとの層間変位追従性能 L はラスモルタルが L2、サ イディングと ALC パネルが L4 となった。乾式の外壁構法がい ずれも高い性能を有していることがわかる。

5 ) 実際の市街地において外壁の地震時損傷リスク D を評価した結 果、重点整備地域に指定されている中野区 $\mathrm{M}$ 地域はそのリス クが高く、郊外住宅団地である八王子市 $\mathrm{N}$ 地域は低くなった。 ただし、八王子市 $\mathrm{N}$ 地域においても 3 割強の建物について外壁 損傷のリスクが高く、他の地域危険度による評価ほど安全では ないことを示唆する結果が出ている。

注

注 1 ）ここでいう全壊・半壞とは、1968 年に出された「被害認定統一基準」 によるものであり、被災者への義捐金の配分、固定資産税の減免措置な どの判断材料とする事を目的に行われるものである。判定基準は、住家 の損壊部分が延床面積の $70 \%$ 以上もしくは主要構造部の被害額が住家 の時価の $50 \%$ 以上が「全壊」、住家の損壊部分が延床面積の $20 \%$ 以上 $70 \%$ 未満もしくは主要構造部の被害額が住家の時価の $20 \%$ 以上 $50 \%$ 未 満が「半壊」としている。2001 年に内閣府によって基準が改められ、半
表 8 八王子市 $\mathrm{N}$ 地域の外壁損傷リスク

\begin{tabular}{|c|c|c|c|c|c|c|c|}
\hline \multirow{2}{*}{\multicolumn{2}{|c|}{ 八王子市N地域 }} & \multicolumn{5}{|c|}{ 外壁構法の層間変位追従性能 } & \multirow{3}{*}{$\frac{\text { 合計 }}{}$} \\
\hline & & \multirow{2}{*}{$\frac{\mathrm{L} 5}{0}$} & \multirow{2}{*}{$\frac{\mathrm{L} 4}{31}$} & \multirow{2}{*}{$\frac{\mathrm{L} 3}{8}$} & \multirow{2}{*}{$\frac{\mathrm{L} 2}{36}$} & \multirow{2}{*}{$\frac{\mathrm{L} 1}{16}$} & \\
\hline$\hat{n}$ & $\mathrm{~F} 1$ & & & & & & \\
\hline$\frac{1}{2}$ & F2 & 0 & 0 & 0 & 0 & 0 & 0 \\
\hline 签 & F3 & 0 & 2 & 0 & 35 & 15 & 52 \\
\hline 椋 & $\mathrm{F} 4$ & 0 & 0 & 0 & 1 & 0 & 1 \\
\hline 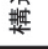 & F5 & 0 & 0 & 0 & 0 & 0 & 0 \\
\hline \multicolumn{2}{|c|}{ 合計 } & 0 & 33 & 8 & 72 & 31 & 144 \\
\hline
\end{tabular}

表 9 杉並区 M 地域の外壁損傷リスク

\begin{tabular}{|c|c|c|c|c|c|c|c|}
\hline \multirow{2}{*}{\multicolumn{2}{|c|}{ 杉並区A地域 }} & \multicolumn{5}{|c|}{ 外壁構法の層間変位追従性能 } & \multirow{3}{*}{$\frac{\text { 合計 }}{12}$} \\
\hline & & \multirow{2}{*}{$\frac{\mathrm{L} 5}{0}$} & \multirow{2}{*}{$\frac{\mathrm{L} 4}{7}$} & \multirow{2}{*}{$\frac{\mathrm{L} 3}{2}$} & \multirow{2}{*}{$\frac{\mathrm{L} 2}{1}$} & \multirow{2}{*}{$\frac{\mathrm{L} 1}{2}$} & \\
\hline$\hat{x}$ & $\mathrm{~F} 1$ & & & & & & \\
\hline 2 & F2 & 0 & 9 & 4 & 36 & 14 & 63 \\
\hline 箩 & F3 & 0 & 0 & 3 & 8 & 8 & 19 \\
\hline$\underset{t|a|}{*}$ & $\mathrm{~F} 4$ & 0 & 0 & 0 & 3 & 4 & 7 \\
\hline 㒘 & F5 & 0 & 0 & 0 & 0 & 0 & 0 \\
\hline \multicolumn{2}{|c|}{ 合計 } & 0 & 16 & 9 & 48 & 28 & 101 \\
\hline
\end{tabular}

表 10 中野区 M 地域の外壁損傷リスク

\begin{tabular}{|c|c|c|c|c|c|c|c|}
\hline \multirow{2}{*}{\multicolumn{2}{|c|}{ 中野区M地域 }} & \multicolumn{5}{|c|}{ 外壁構法の層間変位追従性能 } & \multirow{2}{*}{ 合計 } \\
\hline & & L5 & L4 & L3 & L2 & L1 & \\
\hline \multirow{5}{*}{ 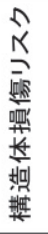 } & $\mathrm{F} 1$ & 0 & 11 & 2 & 4 & 0 & 17 \\
\hline & F2 & 0 & 4 & 4 & 21 & 9 & 38 \\
\hline & F3 & 0 & 0 & 0 & 8 & 17 & 25 \\
\hline & F4 & 0 & 3 & 0 & 5 & 11 & 19 \\
\hline & F5 & 0 & 0 & 0 & 0 & 0 & 0 \\
\hline \multicolumn{2}{|c|}{ 合計 } & 0 & 18 & 6 & 38 & 37 & 99 \\
\hline
\end{tabular}

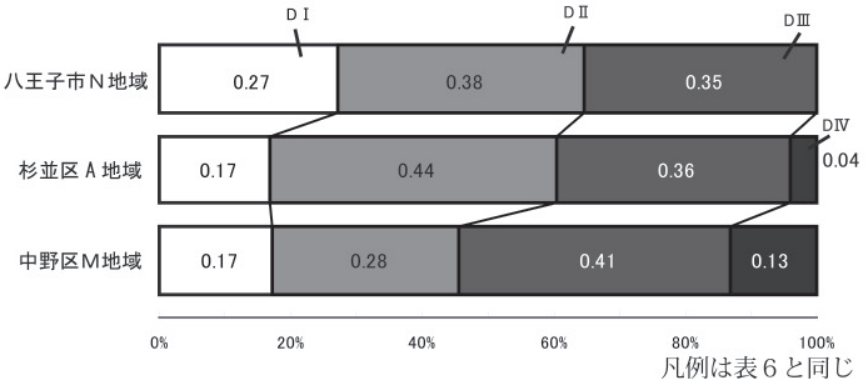

図 2 各市街地の外壁損傷リスクの比較

壊の中でも損傷 述床面積の割合が $50 \%$ 以上 $70 \%$ 未満のものを「大規模 半壞」としている。

注 2 ） 戸建住宅において多く用いられていると考えられる ALC 薄形パネル は、タッピングねじや木刘じを用いて下地材に直接取り付けられる構法 が主である。従って、ロッキング構法やスウェイ構法とは異なる層間変 位追従性能を示すと考えられるが、ALC 薄型パネルの取付け構法の層間 変位追従性能を表した資料は見られなかった。本研究では、ALCパネル については層間変位追従性能が高いロッキング構法やスウェイ構法が戸 建住宅の外壁構法として採用されてとして分析を行っている。

注 3 ）昭和 55 年告示第 1790 号によって定められる特定建築物に関しては、 建築基準法施行令第 82 条の 2 において、「建築物 の地上部分については、 地震力によって各階に生ずる水平方向の層間変形角が $1 / 200$ （地震力に よる構造耐力上主要な部分の変形によって建築物の部分に著しい損傷が 
生ずるおそれのない場合にあっては 1/120）以内であることを確かめな ければならない。(一部要約)」とある。

\section{参考文献}

1）東京都：首都直下地震による東京の被害想定 報告書、2006.5

2) 東京消防庁：地震時における市街地大火の延焼性状の解明と対策、火㷋 予防審議会答申、1985 年

3）東京消防庁：地震火災に関する地域の防災性能評価手法の開発と活用 方策、火災予防審議会答申、2001 年

4) 濱崎信子、ほか 5 名：木質系住宅の地震時損傷状況に関する実験的研究 その 2 損傷と相関変形角の関係 (外装等)、日本建築学会大会学術講演 梗概集（東海）C-1 分冊、pp.361-362、2003.9

5 ) 早崎洋一、ほか 5 名 : 木質系住宅の地震時損傷状況に関寸る実験的研究 その 6 損傷と相関変形角の関係 (壁面実験結果)、日本建築学会大会学 術講演梗概集（北海道） C-1 分冊、pp.93-94、2004.8

6 ）宮村雅史、ほか 5 名：ラス下地モルタル塗り外壁の強度・変形性能と破 壊性状その 1 実験概要と強度変形性能、日本建築学会大会学術講演梗 概集（九州） C-1 分冊、pp.213-214、2007.8

7 ）西山栄一、ほか 5 名：ラス下地モルタル塗り外壁の強度・変形性能と破 壊性状その 2 直張りの破壊性状、日本建築学会大会学術講演梗概集（九 州) C-1 分冊、pp.215-216、2007.8

8 ) 大橋好光、坂本功 : 木造軸組ラスモルタル壁の水平せん断実験（その 2 ）、 日本建築学会大会学術講演梗概集（東北）構造系、pp.2079-2080、1982.10

9) 宮村雅史、太田正光、山口修由：ラス下地モルタル塗り工法の耐力及び 剥落に関する研究 - ラス下地板の場合一、日本建築学会大会学術講演 梗概集（北海道）、pp.475-476、2004.8

10）綿引誠、ほか 3 名：木造軸組構法における非構造部材の動的・静的挙動 と建物の性能設計に関する実験的研究 (その 2 ) 外装、日本建築学会大会 学術講演梗概集 (九州) C-1 分冊、pp.509-510、2007.8

11）水谷吉克、ほか 7 名：ALCロッキング構法実大変形追従性試験 その 4 ～5、日本建築学会大会学術講演梗概集 (九州) A-1 分冊、pp.113-116、 1998.9

12）高橋大祐、ほか 3 名：内装仕上げを施した ALC 二次壁の動的変形能 試験その 1 、その 2 、日本建築学会大会学術講演梗概集（北陸）構造系、 pp.359-362、2002.8

13）浅井英克、時野谷浩良、鈴木康正 : 鉄骨造建物における横張り乾式外 壁の相関変形追従性能確認試験、日本建築学会大会学術講演梗概集（九 州) C-1 分冊、pp.1059-1060、2007.8

14）横家尚、ほか 3 名：現場タイル張り ALC パネルの層間変位追従性能に 関する実験的研究 その $1 \sim 3$ 、日本建築学会大会学術講演梗概集（北 陸） A-1 分冊、pp.353-358、2002.8
15）松岡祐一、ほか 3 名：開口部のある ALC 版外装材の大変形性能検証実験 $\mathrm{E}$ ーディフェンス鋼構造建物実験研究その 14、日本建築学会大会学術講 演梗概集（九州）C-1 分冊、pp.1081-1082、2007.8

16）坂本功、ほか 4 名：ALC パネル外壁の耐震性に関する実験的研究 その $1 \sim 3$ 、日本建築学会大会学術講演梗概集（近畿）A 分冊、pp.201-206、 1987.10

17）永井昌志、山崎健一、河辺伸二：現場タイル張り ALC パネル縦壁ロッキ ング構法の層間変位追従性能に関する実験的研究 その 1 . 層間変位追従 性能試験結果、日本建築仕上学会大会学術講演会研究発表論文集、 pp.125-128、1998.10

18）金子美香、神原浩、田村和夫 : 非構造部材の耐震実験結果に基づく耐震 性能の整理、日本建築学会技術報告集第 21 号、pp. 39-44、2005.6

19）長谷部浩一、翠川三郎、松岡昌志：地域メッシュ統計を利用した広域で の木造建物群の震害予測その 2 建築年代別木造建築物の被害関数の作 成と震害予測例、日本建築学会構造系論文集 第 505 号、pp. 53-59、 1998.3

20）長谷部浩一、翠川三郎：地域メッシュ統計を利用した広域での非木造建 物群の震害予測、日本建築学会構造系論文集 第 521 号、pp. 41-47、 1999.7

21）村尾修、山崎文雄 : 自治体の被害調査結果に基づく兵庫県南部地震の建 物被害関数、日本建築学会構造系論文集 第 527 号、pp. 189-196、 2000.1

22）村尾修、ほか 3 名：兵庫県南部地震の被害データに基づく建物倒壊危険 度評価法の提案、日本建築学会構造系論文集 第 527 号、pp. 197-204、 2000.1

23）林康裕、ほか 3 名：耐震診断結果を利用した既存 $\mathrm{RC}$ 造建築物の地震リ スク表示、地域安全学会論文集 No.2、pp. 235-242、2000.11

24）岡田成幸、高井伸雄: 木造建築物の損傷度関数の提案と地震防災への適用、 日本建築学会構造系論文集 第 582 号、pp. 31-38、2004.8

25）（社）建築・設備維持保全推進協会、（財）日本建築防災協会 : 外壁の地 震に対する安全性の評価方法・同解説、2004.3

26）東京都都市整備局：地震に関する地域危険度測定調査報告書、2008.2

27）坂本功、伊藤弘：2 次部材の耐震設計に関する一考察、日本建築学会大 会学術講演梗概集 (東海) 構造系、pp.673-674、1976.10

28）小松幸夫、遠藤和義：戸建住宅のライフサイクルコストの推計、日本建 築学会計画系論文集 第 534 号、pp. 241-246、2000.8

29）齋藤茂樹、深尾精一、門脇耕三 : 戸建住宅の外壁改修周期に関寸る研究 複数の市街地における比較分析、日本建築学会計画系論文集 第 615 号、 pp. 61-67、2007.5

(2008年10月 8 日原稿受理, 2009年 3 月23日採用決定） 